\title{
Chapter 6 Marga's Dos Orillas ${ }^{1}$
}

Time,

like a cartographer,

Heartbreaking

Charts

The painful journey.

If one could 'know' from outside

the beatings of the heart of such and such person (the speaker), one would learn much of the exact meaning of his words.

Henri Lefebvre, Rhythmanalysis: Space, Time and Everyday Life (2004)

The cult of the Sacred Heart as we know it is based on a series of apparitions St. Margaret Mary Alacoque (1647-1690), a French nun from the Holy Mary Visitation Order, received in which Jesus offered her His heart and instructed her to spread the cult. ${ }^{2}$ The first apparition took place on the Feast of St. John the Evangelist on December 27,1673 . The nun tells of her exchange with Jesus as follows:

He said to me: 'My Divine Heart is so passionately inflamed with love for mankind, and for you in particular, that, not being able any longer to contain within itself the flames of its ardent charity, it must needs spread them abroad through your means, and manifest itself to men, that they may be enriched with its precious treasures which I unfold to you, and which contain the sanctifying and salutary graces that are necessary to hold them back from the abyss of ruin. ${ }^{3}$

\footnotetext{
1 Marga, interview by author, Miami, August 4, 2010.

2 On the Cult of the Sacred Heart in France see: Raymond Jonas, France and the Cult of the Sacred Heart: An Epic Tale for Modern Times (Berkeley: The University of California Press, 2000).

3 "Devotion to the Sacred Heart of Jesus: Historical Origin," October 2, 2020. http://www.salve mariaregina.info/Reference/Sacred\%20Heart.html.
} 
Baptized in honor of St. Margaret Mary Alacoque, Marga, a professor of Early Modern Spanish History, knows the story well. Like her namesake saint, she spread the message of the heart in a life filled with love and charity for others. It is her giving spirit that marks her remarkable journey from one shore of the Atlantic to the other.

\section{To Puerto Rico and Back (infancia y años formativos)}

Marga was born on a cold January morning in Madrid in 1953. Her parents met in Madrid where her father, Tomás, a Puerto Rican, was studying medicine at the Universidad Complutense and her mother, Esperanza, was a secretary in the INI. Esperanza had grown up in Asturias, in a well-to-do family. Her grandfather had been the Consul of Brazil but fell into trouble with the Francoist authorities after issuing passports for those escaping the civil war.

After marrying, the couple spent the first decade of their marriage starting a family and moving them back and forth between Puerto Rico and Spain before finally settling in the coastal town of Almuñécar on the Costa Tropical in the province of Granada. With her parents estranged by this time, and her father back in Puerto Rico, Marga would make the province of Granada her permanent home.

Almuñécar was a sleepy fishing village that experienced an economic boom from sugar cane production in the 1950s. The first time Tomás and Esperanza visited the seaside town was in response to an invitation from some friends they had met in Madrid. That summer of 1952, early in her pregnancy with Marga, Esperanza packed her Jantzen bathing suit, anticipating some swimming in the Mediterranean. It did not take long before she noticed how the local men started to sit close by and stare. To the locals, a woman showing her thighs on the beach represented an immoral display. Back then women wore knee length skirts over their bathing suits. Esperanza always made a point to reminisce about the prudish mores of the town and how she had to comply with the swimming skirt herself.

By the 1960s, when Marga was coming of age, much had changed in the coastal town and in Spain itself. Gone were the bathing skirts, replaced by formfitting modern one-piece suits and even bikinis, worn by an invasion of northern European tourists lured to the coast by the regime's economic development initiatives. By encouraging the waves of tourism to splash upon its shores, Spain was also inadvertently allowing a more progressive view of women to roll across a new generation of young girls.

When it came time for Marga to enter middle school, her mother decided that more educational opportunities were available inland in the region's capital of Granada. Marga attended the Teresian Institute middle school, founded in 1911 
by Father Pedro Poveda (1874-1936). ${ }^{4}$ The Teresians were an all-female secular order created to train women as teachers and fulfill the ideal union between faith and knowledge. ${ }^{5}$ The school was a good fit for the studious young girl who was already thinking about college. The Catholicism imparted in the Teresian school was deeply rooted in the Vatican Council II and led Marga to a better understanding of injustice. This was a theme that was to stay with her when she entered the Instituto Padre Manjón, a lay magnet high school under the purview of the University of Granada. Marga remembers the Instituto as the place where she became interested in leftist politics and feminism. She read Durkheim, Margaret Mead, Lucy Mair, Betty Friedan, Caro Baroja, the Informes FOESSA, and a new research journal, Cuadernos Para el Diálogo. ${ }^{6}$ From her readings and discussions with likeminded students, her nascent curiosity about feminism was born, a curiosity that would lead to a lifelong passion for female justice and fairness.

When Marga entered college, she joined FECUM ${ }^{7}$ because the Jesuits matched her political and social outlook at the time. FECUM was also a social network for the young students who became a close-knit group of friends. They went to the movies together, discussed the works of Julio Cortázar and Mario Vargas Llosa, hiked in the mountains, and shared many late nights discussing their futures. "We felt so alive," she reminisced. "We read a lot of Marxism. It was the theory that made sense to us because it explained so many things, lent coherence to many religious precepts we had internalized since childhood." Even though the goals of FECUM and the Communist party were aligned, the Communist party was more forceful in its stance against the regime's treatment of the poor and working class. Whereas the Catholic group was content with gradual, long-term change, the Communists wanted revolution. Marga, like many of the students, was being gradually pulled leftward. "Marxism put at our disposal the instruments to build a more just social order," she explained. "We read Lenin alongside Paulo Freire, Marcuse, and Wilhelm Reich. We demanded that our professors include these extracurricular readings in our classroom discussions."

Marga eventually joined the Communist party but did not abandon her friends in FECUM. Always the mediator, she was helpful in negotiations between the two

4 Canonized in 2003 by Pope John Paul II.

5 See Morcillo, True Catholic Womanhood.

$6 \quad$ Cuadernos was the first current affairs magazine of Spain established in October 1963 until 1978. Originally it was a Christian democratic publication that evolved to become center-left and later socialist. This publication, along with Triunfo, were the two political journals that advocated for democratic reforms during the transition to democracy.

7 Federación Española de Congregaciones Marianas Universitarias (Spanish Federation of University Marian Congregations) founded by the Jesuits in the 1960s. See Juan Carlos Sainz Martínez, "De FECUM a FECUN: Política y Religión entre los Congregantes Marianos (1965-1977)," Política y Sociedad, 22 (1996): 103-21. 
groups. She had grown up partly in a democratic system, the United States territory of Puerto Rico, which gave her a perspective that many of her fellow students did not have. She understood especially how messy democratic systems were, and that absolutism was not something that worked in an open society.

Even though she was fighting for a better society for all, she felt that she had a special role to fight for the emancipation of women. Many of her male comrades felt that women's struggles were secondary and needed to be set aside for the good of the larger cause, the dissolution of the Franco regime. This underlying sexism in the movement led her to seek out other women in the party. Socorro and Amparo, women a couple of years older than Marga, were her heroes and role models. They had endured the worst of the government's repression and had shown that women could fight and endure every bit as well as men.

\section{Transformative Journey of the Heart (abortion \& feminism)}

The women Marga admired had put aside many of their reservations about the male-dominated student movement in order to achieve the larger objective of transforming Spain into a more democratic nation. Once that goal was achieved, women like Marga, following in their wake, were not going to be as accommodating. Marga belonged to a new generation of young women faculty under contract to teach at the university. She and others were given low salaries and occupied the lowest rank of faculty at the university. They were expected to be satisfied that they had been given a seat at the academic table, while the men still sat at its head.

Despite the ongoing struggles, the early 1980 os were promising years for women in many ways. The socialists won control of parliament in the 1982 election and quickly established the post of Secretary of Women (Instituto de la Mujer), appointing the feminist Carlota Bustelo to lead it. For the first time since the Second Republic, leftist women occupied positions of power in the Spanish government. More women than ever were filling seats in colleges and imagining careers that were previously blocked to them. Social mores were changing, reflected in the depiction of women in movies and television. The "Madrid Movida" (la Movida Madrileña) was in full bloom, and in 1986, Pedro Almodóvar's Women on the Verge of a Nervous Breakdown won the Academy Award Oscar for best foreign film.

Not every change after the transition was necessarily advantageous to women, even if advertised that way. The "destape" (literally meaning "uncovering") of women's bodies became a metaphor to discuss the opening of the political system and women's role in the new democracy. The wave of eroticism and sexual freedom that followed the transition was advertised as a liberation for women as well as men. Feminists like Marga, in hindsight, see it as often less liberating than promised. 
The new narrative of sexual freedom, ironically, felt to many newly emancipated women like another form of subjugation. Being free to have sex without care or commitment might have fit the male fantasy of female liberation, but it presented a whole other host of other dilemmas for women. Sexual harassment by men, even men in the resistance movement, was allowed to flourish under the guise of sexual freedom. Now women were free to be harassed by both friend and foe with little of the protections built into the more conservative norms of earlier times. Reproductive issues also remained largely a female problem, with newly liberated men often using sexual liberation to avoid responsibility for their actions.

At the university, the men were not in a hurry to open up the academy to a more female-centered curriculum or pedagogy. They might have made radical changes to the curriculum in their view, but from a woman's perspective, it looked a lot like swapping out one group of male thinkers for another. Marga remarked, "Our male peers questioned the intellectual value of writing about gender issues, about women's experiences. When we would bring it up in meetings, they acted like we were throwing a tantrum. Sometimes they would deign to let us 'pretend' to be scholars, leaving them access to the plum professorships and administrative positions."

Marga's feminist consciousness did not suddenly emerge during the liberal 1980 s but had been growing since she was a teenager. She remembers reading Betty Friedan's The Feminine Mystique (1963) and Simone de Beauvoir's The Second Sex (1949) in high school and becoming aware on an intellectual level of the different experiences women faced in society. She remembers being cognizant of the double standard for behavior when she got her first boyfriend. "My first real kiss was experienced while walking in the gardens of Los Mártires, where lovers used to stroll and steal caresses and kisses under the protection of trees and manicured shrubs," she remembered. Afterward, she was worried about her reputation and then became angry when she realized that women were the only ones who had to worry about their "reputation." "Men never faced the same scrutiny and were even looked up to for their sexual conquests," she remarked. Women in traditional Spanish culture were placed into two camps, whores and virgins. There was no middle ground to explore your sexuality as a woman in this bipolar world. Many women patiently endured years of long courtships before having sex, often awkward and painful, on their wedding night. Further, the regime's prohibition of birth control and abortion made sex seem more like a game of Russian Roulette than a consummation of desire. This virginal straitjacket might have been acceptable to earlier generations of Spanish women, but for a college-educated woman, raised on second-wave feminist writings and exposure to more liberal western European mores, this was untenable.

Being part of a self-identified coterie of feminists came with challenges for Marga and her colleagues. There were a series of unwritten codes to follow to fit 
into the mold of the "feminist." "We hid our bodies," Marga said, "learning to dress not so much to seduce but to please. We dressed and carried ourselves in a more stereotypically masculine way in order to be taken more seriously by the men." The women of Marga's generation also had much more agency in their relationships with men. "I could not understand how couples in Granada could last in courtships for seven, eight, or even ten years without having sex. I decided when and with whom to lose my virginity. I picked the guy and regarded the entire experience as a transactional act. I must say, it was a pretty disappointing experience as he was not very skilled. But I later had other relationships and enjoyed my sexuality completely, never considering it linked with marriage or love. I never thought that monogamy and exclusivity was essential for a relationship to last but rather open communication and commitment to not hurting each other." This type of thinking would have been reputational suicide for a woman under the regime but was widely becoming the norm in cosmopolitan Spain in the 1980s.

Marga's first true love was Lalo. She was already in her senior year of college, and he was a freshman, a free spirit with an artist's soul who was pursuing an Art History degree. She recruited him to join the Plataformas Universitarias de Estudiantes (University Student Platforms). Lalo and Marga were drawn to each other by their shared political activism. This led them to move in together in one of the poorer neighborhoods in Granada, El Polígono, where they could live and work to improve the conditions from the inside as true members of the neighborhood association. Even though they did not believe strongly in the institution of marriage, the practicality of it made sense to them. They would be married in 1980 only to separate eighteen months later. "We had had problems for a while because we had diametrically different life goals. We grew apart. I was more practical, needed to finish my dissertation, had to fight to find a space in the university and wanted to grow academically. Lalo was a bohemian spirit, disillusioned after he finished Art History, lost and not knowing where to go." Marga's deteriorating marriage led her to make another difficult decision. She became pregnant at a time when the relationship was past salvaging and decided to have an abortion.

Having access to safe and legal abortions was something that feminists throughout Europe and the United States had fought for since the beginning of the student movement. Abortion and birth control were essential to removing the biological handcuffs that had been restraining women. Birth control allowed women to uncouple sex from reproduction, and abortion gave them the power to decide their fate if they inadvertently got pregnant. If women were to have equal opportunities and some semblance of parity with men, both needed to be freely available. In Spain, abortion was still illegal when Marga made the decision to not carry her pregnancy to term. This meant that she, like many other Spanish women of her generation, had to go outside the country to have a safe and legal abortion. 
Marga opened up about her experience: "I traveled to Holland and had an abortion: the most difficult decision of my life. I did not have the freedom to have or not to have children...to put it somehow in words...and to this day it hurts. My relationship with Lalo was finished, and I believed I could not raise a child alone nor was I willing to be a single mother. I was convinced. And later over the years some women my age had babies and I reconsidered it, but I came to the realization that I was not willing to have a child to fill the emotional void of not having a partner in my life. So, I have never regretted my decision, although it was extremely painful."

"That trip was devastating, painful, frightening. I went to Holland because the abortion providers were part of a feminist network, while in London it was just a business. I don't remember exactly who gave me the information, but there were channels like the feminist group around the bookstore Librería de Mujeres, and within the MC I also assisted in counseling some girls and on some occasions, colleagues. Having an abortion abroad was very expensive and only those with means could afford it. I paid 65,000 or 70,000 pts in 1981. That included a roundtrip flight, hotel, and the procedure. It was a little odyssey, you know. I always forget something when I travel. I left so sad because I had to go alone. I didn't have money to pay for someone to go along with me. Through the MC party I arranged to stay with a comrade in Madrid. This particular person was a wonderful guy who worked in a travel agency and found me a very affordable flight and hotel. He really helped and gave me a referral to a tour called 'Amsterdam en vaqueros' (Amsterdam in jeans), the best guided tour in the world, and also he recommended a pension across from the Central Train Station that served the most wonderful breakfast. I did not speak a word of Dutch and only some broken English. When I arrived, I took a nap and then started unpacking when I realized I had forgotten the address of the abortion clinic. I called Lalo at his father's home and asked him to look for the address, but he could not find it. Disastrous! Back in the hotel I looked in the travel guidebook. Flipping through the pages I found a women's center in Amsterdam. I decided they might be able to help me, so I took a taxi there. I was so worried about spending too much money that when I entered the center, so upset, I could not explain what I needed to the receptionist. After a little while I was able to tell them in broken English what my circumstances were. It so happened that this Women's Center was part of the same network and was able to tell me the address where I had to go the next day. I took a train and a taxi because the clinic was very far from my hotel. They were excellent professionals and treated me so well. The nurse who assisted me spoke Spanish. She told me she was Catholic and felt it was important for women to have choices. I was supposed to be in the clinic only a few hours, but they kept me there longer to make sure that I was not hemorrhaging. After a time, they let me go. I cried disconsolately...I was profoundly distraught, so lonely. I will never forget it happened in early September, on Saturday the $11^{\text {th }}$. The morning after, I was bleeding heavily but got out of bed and went out on the street where 
I ran into a rally led by Chilean exiles in remembrance of the ten-year anniversary of the Pinochet coup d'état. I joined the march and screamed with them against that aborted revolution of theirs that we from Spain had hoped would succeed. I felt enraged, bleeding inside and out and so profoundly defeated."

The experience of her failed marriage and subsequent abortion only strengthened Marga's resolve to fight for women's rights. She, like a lot of women of her generation, had been disappointed that the transition did not bring about the radical changes to women's lives that were promised. Access to birth control and abortion, taken for granted in most Western European countries, was still illegal in Spain in the early 1980s. Violence against women was commonplace. Discrimination and harassment in the job market was tolerated.

It was in this atmosphere that Marga brought together some graduate students in 1984-85 and established the Seminario de Estudios de la Mujer and later organized the First Symposium on Women's Studies at the University of Granada in 1987 with international keynote speakers such as economist Lourdes Benería from Cornell University and historian Paola Di Cori from the University of Urbino. It is because of what she had seen and experienced that Marga continued to fight for women's rights at the university and beyond. 